\title{
Estrogen receptor $\alpha$ mediates the nongenomic activation of endothelial nitric oxide synthase by estrogen
}

\author{
Zhong Chen, ${ }^{1}$ Ivan S. Yuhanna, ${ }^{1}$ Zoya Galcheva-Gargova, ${ }^{2}$ Richard H. Karas, ${ }^{2}$ \\ Michael E. Mendelsohn, ${ }^{2}$ and Philip W. Shaul ${ }^{1}$ \\ ${ }^{1}$ Department of Pediatrics, University of Texas Southwestern Medical Center, Dallas, Texas 75235, USA \\ ${ }^{2}$ Molecular Cardiology Research Institute, New England Medical Center and Tufts University School of Medicine, \\ Boston, Massachusetts 02111, USA \\ Address correspondence to: Philip W. Shaul, Department of Pediatrics, University of Texas Southwestern Medical Center, \\ 5323 Harry Hines Boulevard, Dallas, Texas 75235-9063, USA. Phone: (214) 648-2015; Fax: (214) 648-2481; \\ E-mail: pshaul@mednet.swmed.edu
}

Received for publication September 28, 1998, and accepted in revised form December 15, 1998.

\begin{abstract}
Estrogen is an important vasoprotective molecule that causes the rapid dilation of blood vessels by activating endothelial nitric oxide synthase (eNOS) through an unknown mechanism. In studies of intact ovine endothelial cells, $17 \beta$-estradiol $\left(\mathrm{E}_{2}\right)$ caused acute (five-minute) activation of eNOS that was unaffected by actinomycin D but was fully inhibited by concomitant acute treatment with specific estrogen receptor (ER) antagonists. Overexpression of the known transcription factor ER $\alpha$ led to marked enhancement of the acute response to $\mathrm{E}_{2}$, and this was blocked by ER antagonists, was specific to $\mathrm{E}_{2}$, and required the $\mathrm{ER} \alpha$ hormonebinding domain. In addition, the acute response of eNOS to $\mathrm{E}_{2}$ was reconstituted in COS-7 cells cotransfected with wild-type ER $\alpha$ and eNOS, but not by transfection with eNOS alone. Furthermore, the inhibition of tyrosine kinases or mitogen-activated protein (MAP) kinase kinase prevented the activation of eNOS by $E_{2}$, and $E_{2}$ caused rapid ER-dependent activation of MAP kinase. These findings demonstrate that the short-term effects of estrogen central to cardiovascular physiology are mediated by ER $\alpha$ functioning in a novel, nongenomic manner to activate eNOS via MAP kinase-dependent mechanisms.
\end{abstract}

J. Clin. Invest. 103:401-406 (1999).

\section{Introduction}

The hormone estrogen classically exerts its effects by modifying gene expression (1-3). However, there are also important rapid, presumably nongenomic, effects of estrogen and other related steroid hormones in a variety of tissues including the vasculature, brain, and bone (4-9). Recent evidence suggests that the vascular effects of estrogen play a critical role in the atheroprotective properties of the hormone (10, 11). Premenopausal women have very little coronary artery disease compared to men, the incidence of the disease rises markedly after menopause, and hormone replacement therapy reduces the risks to premenopausal levels (12-15). In addition, acute estrogen administration rapidly restores the endothelium-dependent dilation of atherosclerotic arteries in primate models, and it acutely improves endotheliumdependent responses in healthy postmenopausal women (16-19). The rapid vasodilatory effect of estrogen is at least partially related to its ability to enhance the bioavailability of nitric oxide (NO) $(10,11,16-19)$, which is a potent regulator of blood pressure, platelet aggregation, leukocyte adhesion, and vascular smooth muscle mitogenesis (20). Endothelial NO is produced by the endothelial isoform of NO synthase (eNOS) upon the conversion of the substrate L-arginine to L-citrulline (20). To better understand the mechanism(s) by which estrogen acutely increases endothelial NO production, the present experiments were performed in cultured endothelial cells to determine the potential role of estrogen receptor (ER) $\alpha$ in this process. We and others have recently shown that estrogen rapidly stimulates eNOS activity in endothelial cells and that ER $\alpha$ is expressed in endothelium (21-24). ER $\alpha$ and the second, more recently discovered ER isoform, ER $\beta$, are known to function as transcription factors mediating estrogen-induced gene expression in both reproductive and nonreproductive tissues $(10,11,25)$. However, ER may also be involved in acute, nongenomic physiologic responses because the rapid effects of estrogen in certain cell types are inhibited by ER antagonists $(4,5,7,8)$.

\section{Methods}

Cell culture. Pulmonary artery endothelial cells (PAEC) were obtained from the intrapulmonary arteries of fetal lambs at $125-135$ days gestation (term $=144$ days) by collagenase digestion and were propagated as described previously (26). These cells have been used previously to evaluate the acute effects of varying oxygenation on eNOS activation (26). Animal care and euthanasia procedures were approved by the Institutional Review Board for Animal Research. Near-confluent PAEC were studied at passage 4-6. COS-7 cells (American Type Culture Collection, Rockville, Maryland, USA) were grown in DMEM (Life Technologies Inc., Grand Island, New York, USA) supplemented with $10 \%$ heat-inactivated FBS plus $200 \mathrm{U} / \mathrm{ml}$ penicillin and $200 \mu \mathrm{g} / \mathrm{ml}$ streptomycin. eNOS activation in whole cells. eNOS activation was assessed in whole cells by measuring $\left[{ }^{3} \mathrm{H}\right] \mathrm{L}$-arginine conversion to $\left[{ }^{3} \mathrm{H}\right] \mathrm{L}$-citrulline during acute incubations, using methods reported previously (21). This procedure provides a direct evaluation of the acute activation of existing eNOS, keeping signal transduction mechanisms intact (27). Adherent cells grown in 24-well plates were placed in L-arginine-deficient, serum-free endothelial-SFM Growth Media (Life Technologies Inc.) for $6 \mathrm{~h}$ and then preincubated in PBS (pH 7.4) containing $120 \mathrm{mM} \mathrm{NaCl}, 4.2 \mathrm{mM} \mathrm{KCl}, 2.5$ 


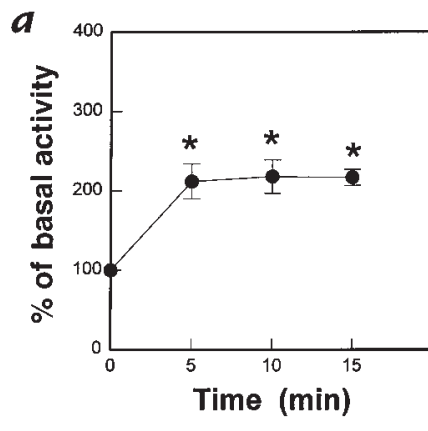

$b$

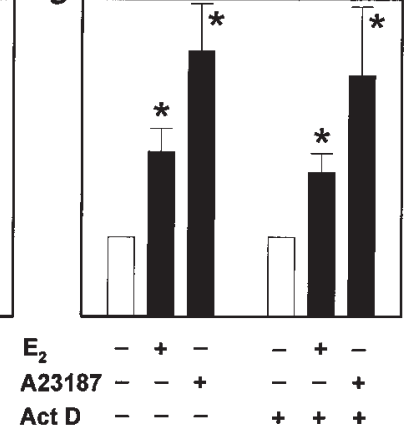

c

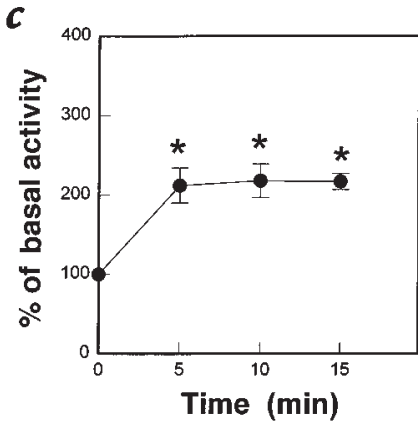

Figure 1

Rapid activation of eNOS in endothelial cells. (a) Effect of $E_{2}$ on eNOS activity in intact PAEC. $\left[{ }^{3} \mathrm{H}\right] \mathrm{L}$-arginine conversion to $\left[{ }^{3} \mathrm{H}\right] \mathrm{L}$-citrulline was measured over 5-15 min in the presence of $10^{-8} \mathrm{M} \mathrm{E}_{2}$. (b) Effect of actinomycin $\mathrm{D}($ Act $D)$ on the rapid activation of eNOS. After 120 min preincubation in the absence or presence of $25 \mu \mathrm{g} / \mathrm{ml}$ Act D, 15 min incubations were done with or without continued Act $D$ and either $10^{-8} \mathrm{M} \mathrm{E}_{2}$ or the calcium ionophore A23187 (10-5 M). (c) Effect of tamoxifen on $E_{2-}$ stimulated eNOS activity. Fifteen-minute incubations were performed in the absence or presence of $10^{-8} \mathrm{M} \mathrm{E}_{2}$, with or without $10^{-6} \mathrm{M}$ tamoxifen (Tam) added simultaneously. Partial inhibition (50\%-70\%) was also noted with $10^{-8} \mathrm{M} \mathrm{Tam}$ (13). (d) Effect of ICl 182,780 on $\mathrm{E}_{2}$-stimulated eNOS activity. Fifteen-minute incubations were performed in the absence or presence of $10^{-8} \mathrm{M} \mathrm{E}_{2}$, with or without $10^{-5} \mathrm{M} \mathrm{ICl} 182,780$ added simultaneously. Full inhibition was also observed with $10^{-6} \mathrm{M} \mathrm{ICl} 182,780$ (13). Values are mean $\pm \mathrm{SEM} ; n=4-6$. ${ }^{*} P<0.05$ vs. basal. $E_{2}$, estradiol-17 $\beta ; e N O S$, endothelial nitric oxide; $P A E C$, pulmonary artery endothelial cells.

$\mathrm{mM} \mathrm{CaCl}_{2}, 1.3 \mathrm{mM} \mathrm{MgSO}_{4}, 7.5 \mathrm{mM}$ glucose, $10 \mathrm{mM}$ HEPES, 1.2 $\mathrm{mM} \mathrm{Na}_{2} \mathrm{HPO}_{4}$, and $0.37 \mathrm{mM} \mathrm{KH}_{2} \mathrm{PO}_{4}$ for $15 \mathrm{~min}$ at $37^{\circ} \mathrm{C}$. The incubation for eNOS activity was initiated by replacing the preincubate solution with PBS containing $1.5 \mu \mathrm{Ci} / \mathrm{ml}\left[{ }^{3} \mathrm{H}\right] \mathrm{L}$-arginine. After 5-15 min, the reaction was stopped by adding 1 N TCA, the cells were freeze-fractured in liquid nitrogen and scraped with a rubber spatula, the contents of each well were ether extracted, and the $\left[{ }^{3} \mathrm{H}\right] \mathrm{L}$-citrulline generated was isolated using Dowex AG50WX8 columns (Sigma Chemical Co., St. Louis, Missouri, USA) and quantified by liquid scintillation spectroscopy. In individual experiments, four to six wells were used for each treatment group. All findings were confirmed in at least three independent studies. Basal $\left[{ }^{3} \mathrm{H}\right] \mathrm{L}$-citrulline generation over 15 min ranged from 4 to 7 fmol/100,000 cells on different experimental days. Results are expressed as the percent of basal eNOS activity determined in the same 24-well plate. To study the acute effects of estrogen on eNOS in PAEC, $\left[{ }^{3} \mathrm{H}\right] \mathrm{L}$-arginine conversion to $\left[{ }^{3} \mathrm{H}\right] \mathrm{L}$-citrulline was measured in whole cells either under basal conditions or in the presence of $10^{-8} \mathrm{M}$ estradiol- $17 \beta\left(\mathrm{E}_{2}\right)$. In previous experiments, the maximal effect of $\mathrm{E}_{2}$ was obtained at $10^{-8} \mathrm{M}$, and the threshold concentration was $10^{-10} \mathrm{M}(21)$. The activation of eNOS was also evaluated in the presence of estradiol- $17 \alpha\left(10^{-12}\right.$ to $\left.10^{-6} \mathrm{M}\right)$ or in the presence of the known eNOS agonist acetylcholine $\left(10^{-6} \mathrm{M}\right)$ or the calcium ionophore $\mathrm{A} 23187\left(10^{-5} \mathrm{M}\right)(21)$. Acetylcholine has been used previously in this cell culture model to mimic mechanisms in intact arteries $(21,28)$, and it has also been used by others in studies of nitric oxide (NO)-release processes in a variety of endothelial cell types (29-31). Both basal and stimulated eNOS activity were fully inhibited by $2.0 \mathrm{mM}$ nitro-L-arginine methyl ester. To determine if the effect of $\mathrm{E}_{2}$ on PAEC eNOS is mediated at the level of gene transcription, cells were treated with $25 \mu \mathrm{g} / \mathrm{ml}$ actinomycin D for 120 min, and eNOS activation was then determined in the continued presence of actinomycin D for $15 \mathrm{~min}$. Studies of cyclooxygenase type 1 and malate dehydrogenase gene expression have revealed that such treatment fully inhibits gene transcription in the PAEC (32). The role of ER in the rapid response to $\mathrm{E}_{2}$ was determined during 15-min incubations done in the absence or presence of $10^{-8}$ $\mathrm{M} \mathrm{E}_{2}$, with or without $10^{-6} \mathrm{M}$ tamoxifen or $10^{-5} \mathrm{M}$ ICI 182,780 added simultaneously (33).

Cell transfection studies. To determine the specific role of ER $\alpha$ in the acute endothelial cell response to $\mathrm{E}_{2}$, the abundance of functional $\mathrm{ER} \alpha$ was augmented by transiently transfecting the expression plasmid $\mathrm{pCMV}_{3}-\mathrm{ER} \alpha$, or $\mathrm{pCMV}_{3}$ alone, into PAEC using Lipofectamine (Life Technologies Inc.) (34). $\mathrm{PCMV}_{3}$-ER $\alpha$ was constructed by cloning full-length human ER $\alpha$ cDNA (35) as an EcoRI fragment into the CMV-driven plasmid pCDNA 3.1 (Invitrogen Corp., San Diego, California, USA). The construct was confirmed by sequencing in both directions. Cotransfection with a plasmid containing SV40-driven $\beta$-galactosidase was performed to normalize for transfection efficiency (34). Transfected cells were placed in phenol red-free, estrogen-free media. Seventy-two hours after transfection, acute $\mathrm{E}_{2}$-stimulated eNOS activation was examined. Enhanced ER-mRNA expression was documented in reverse transcription-PCR assays (21), and greater ER $\alpha$ protein abundance was confirmed by both immunocytochemistry and immunoblot analysis with the mouse monoclonal antibody AER 320 directed against amino acids 495-595 of human ER $\alpha$ (Neomarkers Inc., Fremont, California, USA), using methods described previously (34). Immunocytochemistry for $\beta$-galactosidase revealed successful expression of the protein in 15\%-20\% of cells, and immunostaining for ER $\alpha$ confirmed enhanced expression in $20 \%-40 \%$ of cells transfected with ER $\alpha$ cDNA. To determine the effects of ER $\alpha$ overexpression on estrogen-induced transcriptional transactivation, cotransfection was performed with a luciferase reporter plasmid that contains three copies of the Xenopus vitellogenin estrogen-response element (ERE), ERE-Luc,7 or the control plasmid TK-Luc (34). After transfection, cells were placed in either phenol red-free, estrogen-free media, or phenol red-free media containing $10^{-8} \mathrm{M} \mathrm{E}_{2}$ for $48 \mathrm{~h}$, and reporter activity was measured (34).

Additional experiments were performed to delineate the role of the hormone-binding domain of ER $\alpha$. Acute eNOS activation was assessed in PAEC transfected with $\mathrm{pCMV}_{3}, \mathrm{pCMV}_{3}-\mathrm{ER} \alpha$, or $\mathrm{PCMV}_{3}$-ER $\alpha-271-\mathrm{NTF}$. The latter expression plasmid was constructed by first cloning full-length human $\mathrm{ER} \alpha \mathrm{cDNA}$ into the pCDNA3.1 plasmid, followed by insertion of the coding sequence for the 8-amino acid "Flag" epitope (NTF), recognized by M2 monoclonal antibody (Kodak, Rochester, New York, USA), immediately after the initiation codon at the $5^{\prime}$ end of the ER $\alpha$ coding sequence to yield $\mathrm{PCMV}_{3}$-ER $\alpha-\mathrm{NTF}$. Then $\mathrm{PCMV}_{3}$-ER $\alpha-\mathrm{NTF}$ was digested with $X \mathrm{~cm} 1$ and $X h o 1$ to remove all coding sequence distal to amino acid 271, which excludes the hormone-binding domain (HBD), followed by blunting of the construct ends and religation to yield $\mathrm{pCMV}$-ER $\alpha-271-\mathrm{NTF}$. Expression from these plasmids of both full-length and truncated epitope-tagged proteins of the predicted size was demonstrated by transient transfection of COS-1 cells followed by immunoprecipitation and immunoblot analysis.

To generalize the findings in the native endothelial cells, further studies were done to reconstitute the ER $\alpha$-mediated activation of eNOS in a cell type that does not constitutively express either ER 

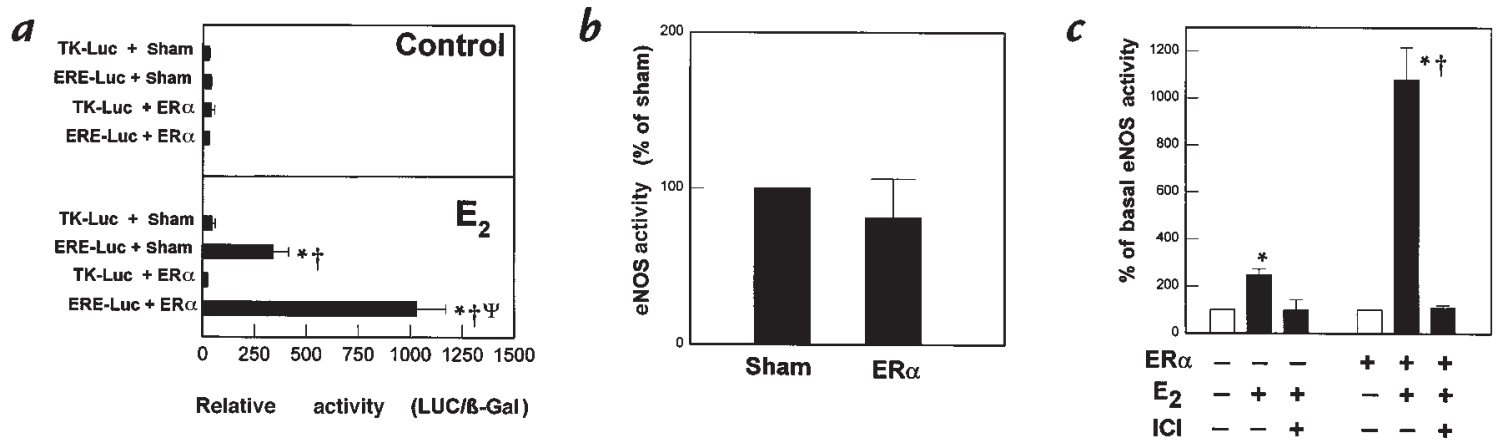

Figure 2

Effect of ER $\alpha$ overexpression on transcriptional transactivation and on basal and $E_{2}$-stimulated eNOS activity. (a) Effect of ER $\alpha$ overexpression on ERE-mediated gene transcription in PAEC. Transient transfections were performed with either the estrogen-responsive reporter plasmid ERE-Luc or the control plasmid TK-Luc, in combination with either sham plasmid or ER $\alpha$ cDNA. Reporter activity was then determined in control cells (upper panel) and cells exposed to $10^{-8} \mathrm{M} \mathrm{E}_{2}$ for $48 \mathrm{~h}$ (lower panel). Reporter activity is expressed as luciferase activity/ $\beta$ galactosidase activity $\left(L U C / \beta\right.$-gal). ${ }^{*} P$ $<0.05$ vs. TK-Luc, ${ }^{\dagger} P<0.05$ vs. control cells, ${ }^{\Psi} P<0.05$ vs. sham. Similar findings were obtained in three independent experiments. $(\boldsymbol{b})$ Effect of ER $\alpha$ overexpression on basal eNOS activity in PAEC. Cells were transfected with sham plasmid or ER $\alpha \mathrm{cDNA}$, and $72 \mathrm{~h}$ later [ $\left.{ }^{3} \mathrm{H}\right] \mathrm{L}-\mathrm{arginine} \mathrm{conversion}$ to $\left[{ }^{3} \mathrm{H}\right] \mathrm{L}$-citrulline was measured over $15 \mathrm{~min}$ in nonstimulated, intact cells. (c). Effect of ER $\alpha$ overexpression on acute eNOS activation by $\mathrm{E}_{2}$. PAEC were transiently transfected with sham plasmid or $\mathrm{ER} \alpha \mathrm{cDNA}$, and $72 \mathrm{~h}$ later $\left[{ }^{3} \mathrm{H}\right] \mathrm{L}$-arginine conversion to [ $\left.{ }^{3} \mathrm{H}\right] \mathrm{L}-\mathrm{citrulline}$ was measured in intact cells over $15 \mathrm{~min}$ in the absence or presence of $10^{-8} \mathrm{M} \mathrm{E}_{2}$, with or without $10^{-5} \mathrm{M} \mathrm{ICI} 182,780$ added simultaneously. Values are mean $\pm \mathrm{SEM}$; $n=$ 4-6. ${ }^{*} P<0.05$ vs. basal, ${ }^{\dagger} P<0.05$ vs. sham. $E R \alpha$, estrogen receptor $\alpha$; $E R E$, estrogen response element.

or eNOS and that is not estrogen responsive. COS-7 cells were cotransfected with human eNOS cDNA (36) and either ER $\alpha$ $c D N A$ or sham plasmid, and the acute effects of $E_{2}$ were assessed.

Tyrosine kinase-MAP kinase inbibition and measurement of MAP kinase activity. Additional studies were performed to begin to elucidate the signal transduction mechanisms involved in acute $\mathrm{E}_{2}$ stimulation of eNOS. In nonendothelial cell types, $\mathrm{E}_{2}$ can cause the rapid activation of several signaling pathways, including those involving c-src-related tyrosine kinases and mitogen-activated protein (MAP) kinases $(7,8)$. Therefore, the effects of specific inhibitors of these signaling pathways on eNOS activation were assessed in intact PAEC. Cells were treated with either the tyrosine kinase inhibitors genistein $(50 \mu \mathrm{M})$ or herbimycin $\mathrm{A}(10$ $\mu \mathrm{M})$ for $20 \mathrm{~h}$, or with the MAP kinase kinase (MEK) inhibitor PD98059 $(50 \mu \mathrm{M})$ for $45 \mathrm{~min}(37,38)$. Acute $\mathrm{E}_{2}$-induced eNOS activation was then evaluated in the continued presence of genistein, herbimycin A, or PD98059 over a 15-min period.

The effect of $E_{2}$ on MAP kinase activity was also assessed (8). PAEC were treated for $5 \mathrm{~min}$ with $10^{-8} \mathrm{ME}_{2}$ in the absence or presence of $10^{-5} \mathrm{M}$ tamoxifen or $10^{-5} \mathrm{M} \mathrm{ICI} 182,780$, or with serum to serve as a positive control. The cells were solubilized with $20 \mathrm{mM}$ Tris buffer ( $\mathrm{pH} 7.5$ ) containing 10\% glycerol, $1 \%$ Triton X-100, 137 $\mathrm{mM} \mathrm{NaCl}, 25 \mathrm{mM} \beta$-glycerophosphate, $2 \mathrm{mM}$ EDTA, $0.5 \mathrm{mM}$ dithiothreitol, $1 \mathrm{mM}$ sodium orthovanadate, $2 \mathrm{mM}$ sodium pyrophosphate, $10 \mu \mathrm{g} / \mathrm{ml}$ leupeptin, and $1 \mathrm{mM}$ phenylmethylsulfonyl fluoride. The extracts were centrifuged at $15,000 \mathrm{~g}$ for 20 $\min$ at $4^{\circ} \mathrm{C}$, and the endogenous kinase was immunoprecipitated from the supernatant by incubation for $2 \mathrm{~h}$ at $4{ }^{\circ} \mathrm{C}$ with polyclonal anti-Erk2 antibody (Santa Cruz Biotechnology Inc., Santa Cruz, California, USA) bound to protein A-Sepharose. The immunoprecipitates were washed twice with the $20-\mathrm{mM}$ Tris buffer and twice with buffer containing 25 mM HEPES ( $\mathrm{pH}$ 7.4), $25 \mathrm{mM} \beta$-glycerophosphate, $25 \mathrm{mM} \mathrm{MgCl}_{2}, 0.5 \mathrm{mM}$ dithiothreitol, and $0.1 \mathrm{mM}$ sodium orthovanadate. Protein kinase assays were then performed using $1 \mu \mathrm{g}$ of myelin basic protein and 50 $\mu \mathrm{M}\left[\gamma^{-32} \mathrm{P}\right]$ ATP $(10 \mathrm{Ci} / \mathrm{mmol})$ in a final volume of $20 \mu \mathrm{l}$ of the 25 mM HEPES buffer. The phosphorylation reaction was linear with time for at least $60 \mathrm{~min}$. The reaction was terminated after $30 \mathrm{~min}$ at $30^{\circ} \mathrm{C}$ by the addition of Laemmli sample buffer. Phosphorylation of the substrate protein was examined after SDS-PAGE by autoradiography and PhosphorImager ( Molecular Dynamics, Sunnyvale, California, USA) analysis.

\section{Results}

eNOS activation by $E_{2}$. The time period over which physiologic concentrations of $\mathrm{E}_{2}$ cause changes in eNOS activity in PAEC is shown in Fig. $1 a . \mathrm{E}_{2}\left(10^{-8} \mathrm{M}\right)$ stimulated an increase in eNOS activity, which reached maximal levels within $5 \mathrm{~min}$ of exposure to the hormone. The response was specific to $E_{2}$, because $17 \alpha$-estradiol $\left(10^{-12}\right.$ to $\left.10^{-6} \mathrm{M}\right)$ had no effect (data not shown). The responses to both $\mathrm{E}_{2}$ and the calcium ionophore A23187 were not altered by the inhibition of gene transcription with actinomycin D (Fig. 1b). To determine if this acute process involves rapid ER activation, the effect of concomitant treatment with the ER antagonist tamoxifen was determined (Fig. 1c). Tamoxifen caused no change in basal eNOS activity but fully inhibited the acute response to $\mathrm{E}_{2}$. In addition, simultaneous treatment with the pure ER antagonist ICI 182,780 also completely negated the rapid, $\mathrm{E}_{2}$-stimulated increase in eNOS activity but did not alter basal activity (Fig. 1d).

Effect of ER $\alpha$ overexpression. The potential role of ER $\alpha$ in acute eNOS activation was evaluated in overexpression studies. To first confirm the overexpression of functional ER $\alpha$, estrogen-induced transcriptional transactivation was assessed by cotransfection of the estrogen-responsive reporter plasmid ERE-Luc or the control plasmid TK-Luc into PAEC with either ER $\alpha$ cDNA or the sham plasmid. In the absence of estrogen, reporter activity was not detectable in any paradigm (Fig. $2 a$, upper). In contrast, after prolonged treatment with $10^{-8} \mathrm{M} \mathrm{E}_{2}$, ERE-Luc reporter activity was eightfold greater than TK-Luc reporter activity in cells having a normal complement of ER (Fig. 2a, lower). Overexpression of ER $\alpha$ caused a further threefold augmentation of estrogen-induced transcriptional transactivation.

The effect of ER $\alpha$ overexpression on basal eNOS activity in intact cells is depicted in Fig. 2b. Basal eNOS activity was unchanged by $\mathrm{ER} \alpha$ overexpression. In addition, immunoblot analysis revealed that eNOS protein abundance was not affected by ER $\alpha$ overexpression (data not 


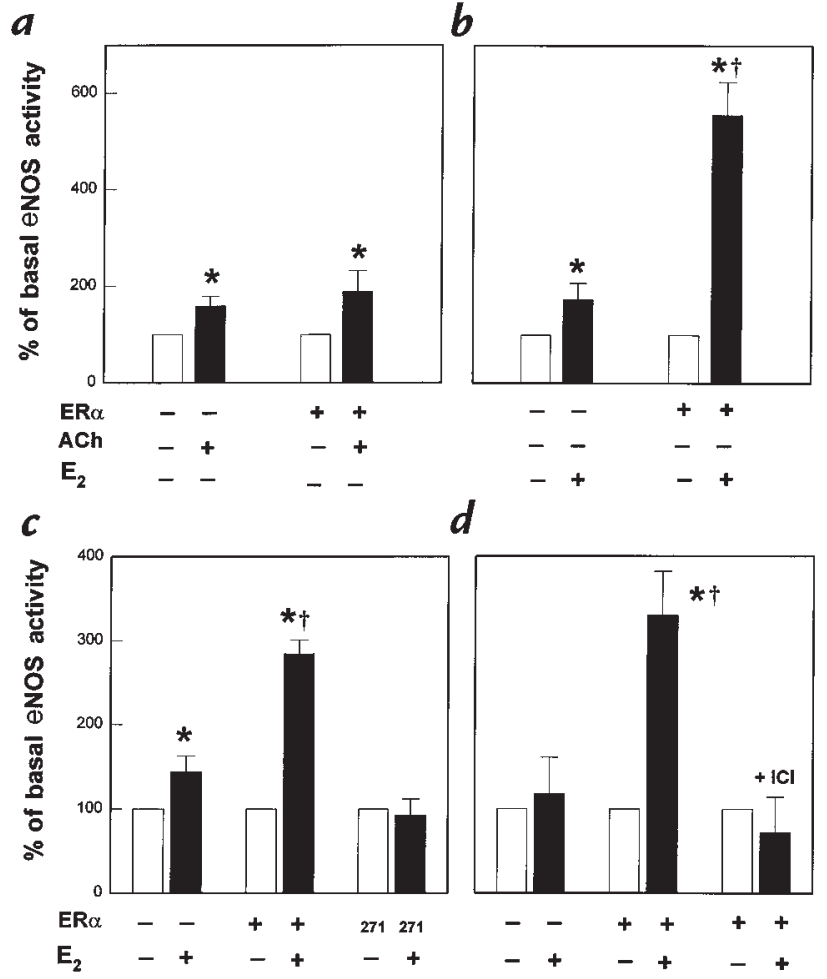

Figure 3

Specificity of the augmentation of eNOS activation by ER $\alpha$ overexpression. ( $\boldsymbol{a}$ and $\boldsymbol{b}$ ) Comparison of the effects of ER $\alpha$ overexpression on acute eNOS activation by acetylcholine $(A C h)$ and $E_{2}$. PAEC were transiently transfected with sham plasmid or with ER $\alpha$ cDNA. After $72 \mathrm{~h},\left[{ }^{3} \mathrm{H}\right] \mathrm{L}$-arginine conversion to $\left[{ }^{3} \mathrm{H}\right] \mathrm{L}$-citrulline was measured in intact cells over $15 \mathrm{~min}$ in the absence or presence of $10^{-6} \mathrm{M} \mathrm{ACh}(a)$, or in the absence or presence of $10^{-8} \mathrm{M} \mathrm{E}_{2}(b)$. (c) Role of HBD in acute eNOS activation by $\mathrm{E}_{2}$. PAEC were transfected with either sham plasmid, wild-type ER $\alpha$ cDNA, or an ER $\alpha$ mutant lacking coding sequence distal to amino acid 271 (labeled 271), which excludes the HBD. The eNOS activity in the absence or presence of $10^{-8} \mathrm{M} \mathrm{E}_{2}\left(15 \mathrm{~min}\right.$ ) was evaluated after $72 \mathrm{~h}$. (d) Reconstitution of acute $\mathrm{E}_{2}$ response in COS-7 cells. Transfections were performed with human eNOS cDNA and either sham plasmid or ER $\alpha$ cDNA, and eNOS activation was measured $72 \mathrm{~h}$ later over $15 \mathrm{~min}$ in the absence or presence of $10^{-8} \mathrm{M} \mathrm{E}_{2}$. Additional studies were done in ER $\alpha$-transfected cells with $10^{-5} \mathrm{M} \mathrm{ICI}$ 182,780 added simultaneously. Values are mean \pm SEM; $n=4-6 .{ }^{*} P<0.05$ vs. basal, ${ }^{\dagger} P<0.05$ vs. sham. $H B D$, hormone-binding domain.

shown). Experiments were then performed to determine the effect of enhanced ER $\alpha$ expression on the acute response to $\mathrm{E}_{2}$ (Fig. 2c). It was found that the rapid response was augmented four- to fivefold in cells transfected with ER $\alpha$ compared to sham-transfected cells (Fig. 2c). Furthermore, the enhanced response was inhibited completely by concomitant acute treatment with ICI 182,780.

To determine the specificity of the augmentation in eNOS activity in response to $\mathrm{E}_{2}$, experiments were done comparing the rapid effects of acetylcholine and $E_{2}$ in PAEC overexpressing ER $\alpha$. With acetylcholine, there were comparable increases in eNOS activity in sham and ER $\alpha$ transfected cells (Fig. $3 a$ ). This contrasted with the augmented response to $\mathrm{E}_{2}$ after ER $\alpha$ transfection (Fig. $3 b$ ). To determine the role of the ER $\alpha \mathrm{HBD}$, additional studies were performed in PAEC transfected with a truncation mutant of ER $\alpha$ lacking coding sequence distal to amino acid 271 (Fig. $3 c$ ). In contrast to the enhanced $\mathrm{E}_{2}$-mediated response observed after wild-type $\mathrm{ER} \alpha$ overexpression, $\mathrm{E}_{2}$ mediated eNOS activity was not augmented in cells expressing the truncation mutant lacking the HBD. To further define the specific role of $E R \alpha$, studies were performed to reconstitute the phenomenon in COS-7 cells that do not constitutively express either ER or eNOS and that are not estrogen responsive. In COS-7 cells transfected with eNOS alone, $E_{2}$ had no effect on eNOS activity (Fig. 3d). However, in cells transfected with both eNOS and $\mathrm{ER} \alpha$, there was a more than threefold increase in eNOS activity upon acute stimulation with $\mathrm{E}_{2}$. In contrast, $\mathrm{ER} \alpha$ expression had no effect on basal eNOS activity $(102 \pm 33 \%$ of activity in sham-transfected cells, or ER $\alpha^{-}$). In addition, activity stimulated by A23187 was unchanged, being 376 $\pm 105 \%$ and $357 \pm 73 \%$ of basal levels in ER $\alpha^{-}$and $E R \alpha^{+}$ cells, respectively. The rapid stimulation of eNOS by $\mathrm{E}_{2}$ in the COS-7 cells transfected with eNOS and ER $\alpha$ was completely inhibited by concomitant ICI 182,780 treatment.

Role of tyrosine kinase-MAP kinase pathway. The role of the tyrosine kinase-MAP kinase signaling pathway in the endothelial cell response to $\mathrm{E}_{2}$ was assessed by both pharmacologic intervention and measurements of MAP kinase activity. The tyrosine kinase inhibitor genistein did not alter basal eNOS activity in the PAEC but completely inhibited the response to $\mathrm{E}_{2}$ (Fig. $4 a$ ). Similar results were obtained with herbimycin A (data not shown). In addition, basal eNOS activity was not modified by the specific MEK inhibitor PD98059, but the stimulatory effect of $E_{2}$ was fully negated by PD98059 (Fig. 4b). Furthermore, a fiveminute exposure to $10^{-8} \mathrm{M} \mathrm{E}_{2}$ caused an increase in MAP kinase activity (Fig. 4c), and this effect was completely inhibited by the ER antagonists ICI 182,780 and tamoxifen.

\section{Discussion}

In this study we have demonstrated that $\mathrm{E}_{2}$ causes acute activation of eNOS in cultured endothelial cells (within five minutes). The response is specific to $\mathrm{E}_{2}$ because $17 \alpha-$ estradiol had no effect. When the rapidity of the response is considered along with the observation that it was not altered by the inhibition of gene transcription with actinomycin $\mathrm{D}$, this suggests that the process does not require the classical nuclear effects of the hormone. However, the acute response was fully inhibited by concomitant acute treatment with the ER antagonists tamoxifen and ICI 182,780 , suggesting that this occurs via rapid ER activation. The specific level of $E_{2}$ that was studied is readily achieved during pregnancy $(39,40)$, and we have previously shown that the response observed in this model is also evident at concentrations that are well below those found in normal cycling women $(21,41,42)$. These cumulative observations are consistent with a novel, nongenomic physiologic role for ER in endothelial cells.

To specifically define the role of $E R \alpha$ in the rapid response to $\mathrm{E}_{2}$, overexpression studies were performed. Overexpression of ER $\alpha$ resulted in augmented estrogeninduced transcriptional transactivation as expected, and it had no effect on the level of basal eNOS activity or eNOS protein abundance in the intact cells. However, the acute response to $\mathrm{E}_{2}$ was augmented four- to fivefold in cells transfected with ER $\alpha$ compared with sham-transfected cells, and the enhanced rapid response was inhib- 
$a$

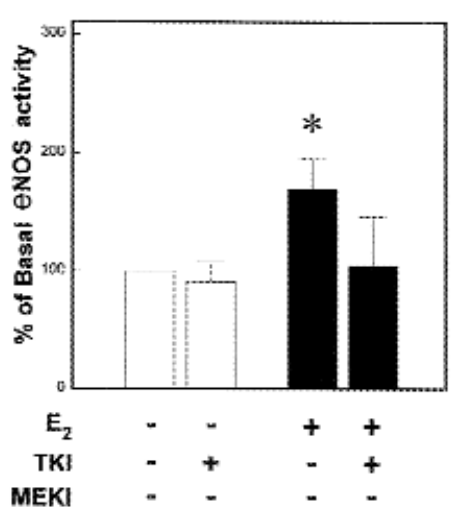

$\boldsymbol{b}$

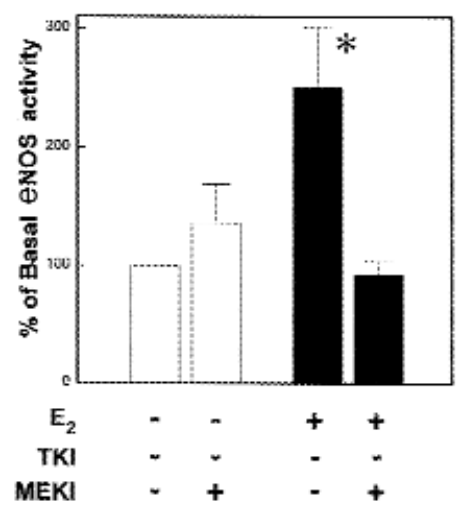

$\boldsymbol{c}$

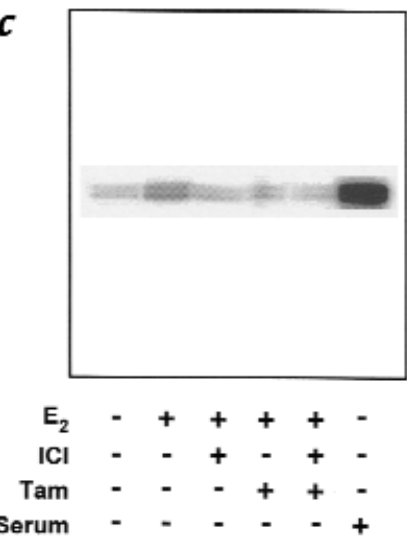

Figure 4

Role of tyrosine kinase-MAP kinase signaling pathway. (a) Role of tyrosine kinase in acute eNOS activation by $\mathrm{E}_{2}$. $\left[{ }^{3} \mathrm{H}\right] \mathrm{L}$-arginine conversion to $\left[{ }^{3} \mathrm{H}\right] \mathrm{L}-\mathrm{cit}-\textrm{ }$ rulline was measured over $15 \mathrm{~min}$ in intact PAEC in the absence or presence of $10^{-8} \mathrm{M} \mathrm{E}_{2}$, with or without treatment with the tyrosine kinase inhibitor (TKI) genistein $(50 \mu \mathrm{M})$. (b) Role of MEK in acute eNOS activation by $E_{2}$. eNOS activity was measured in the absence or presence of $10^{-8} \mathrm{M} \mathrm{E}_{2}$, with or without treatment with the MEK inhibitor (MEKI) PD98059 $(50 \mu \mathrm{M})$. Values are mean $\pm \mathrm{SEM} ; n=4-6 .{ }^{*} P<0.05$ vs. basal. (c) Effect of $\mathrm{E}_{2}$ on MAP kinase activity in PAEC. Cells were treated for 5 min with $10^{-8} \mathrm{M} \mathrm{E}_{2}$ in the absence or presence of $10^{-5} \mathrm{M}$ tamoxifen (TAM) or 10-5 M ICl 182,780, or with serum to serve as a positive control. Endogenous kinase was immunoprecipitated with anti-Erk2 antibody, and protein kinase activity was measured by evaluating the capacity to phosphorylate myelin basic protein. Quantification by Phosphorlmager yielded values of 1, 2.6, 1, 1, 1, and 7.5, respectively, relative to untreated cells. Results shown are representative of five independent experiments. MAP, mitogen-activated protein; MEK, mitogen-activated protein kinase.

ited completely by concomitant acute treatment with ICI 182,780 . These findings suggest that $\mathrm{ER} \alpha$ is capable of mediating the acute response.

To determine the specificity of the augmentation in eNOS activity in response to $\mathrm{E}_{2}$, further experiments were done comparing the rapid effects of acetylcholine and $\mathrm{E}_{2}$ in PAEC-overexpressing ER $\alpha$. With acetylcholine, there were comparable increases in eNOS activity in sham- and ER $\alpha$-transfected cells, which contrasted with the augmented response to $E_{2}$ after $E R \alpha$ transfection. As such, the enhanced acute response to $E_{2}$ in the presence of increased $\mathrm{ER} \alpha$ is specific to the hormone, and it is not due to changes in the expression or function of other components of the eNOS signaling cascade. In contrast to the findings with wild-type ER $\alpha$ overexpression, $\mathrm{E}_{2}$-mediated eNOS activity was not augmented in cells expressing a truncation mutant of ER $\alpha$ lacking the HBD. This is consistent with the inhibition of the acute eNOS response to $E_{2}$ in native endothelial cells by tamoxifen and ICI 182,780, both of which cause ER antagonism via interaction with the ER HBD (10), supporting the conclusion that the HBD of ER $\alpha$ is required for the acute activation of eNOS by $\mathrm{E}_{2}$. Moreover, we have recently found that physiologic concentrations of $\mathrm{E}_{2}$ cause activation of eNOS in isolated plasma membranes from PAEC that is fully inhibited by ICI 182,780 and that ER $\alpha$ protein is readily detectable in the plasma membrane by immunoblot analysis (43). These observations suggest that a specific subpopulation of cell-surface receptors may be involved in the rapid, nongenomic response.

To generalize the findings in the native endothelial cells, experiments were performed to reconstitute the $\mathrm{ER} \alpha$-mediated nongenomic activation of eNOS in a cell type that does not constitutively express either ER or eNOS and that is not estrogen responsive. In COS-7 cells transfected with both eNOS and ER $\alpha$, there was a more than threefold increase in eNOS activity upon acute stimulation with $\mathrm{E}_{2}$, whereas there was no response in cells transfected with eNOS alone. As in native endothelial cells, the rapid activation of eNOS by $\mathrm{E}_{2}$ in the COS-7 cells transfected with eNOS and ER $\alpha$ was completely inhibited by concomitant ICI 182,780 treatment, indicating that the response is mediated by acute ER $\alpha$ activation. Thus, the cotransfection of ER $\alpha$ into cells expressing only eNOS confers the ability of $\mathrm{E}_{2}$ to rapidly activate eNOS, confirming the role of ER $\alpha$ in this process.

Because $E_{2}$ can cause the rapid activation of signaling pathways involving c-src-related tyrosine kinases and MAP kinases in nonendothelial cells $(7,8)$, the potential role of tyrosine kinase-MAP kinase signaling in acute ER $\alpha$-mediated eNOS activation was evaluated. The tyrosine kinase inhibitors genistein and herbimycin A completely inhibited the response to $\mathrm{E}_{2}$. In addition, the specific MEK inhibitor PD98059 also fully negated the stimulatory effect of $E_{2}$. Furthermore, $\mathrm{E}_{2}$ caused a rapid increase in MAP kinase activity in the PAEC, and this effect was prevented by both tamoxifen and ICI 182,780 . These data indicate that the acute stimulation of eNOS by $\mathrm{E}_{2}$ and $\mathrm{ER} \alpha$ entails the activation of tyrosine kinase/MAP kinase. It has been shown that calcium signaling in endothelial cells in response to agonists such as bradykinin involves tyrosine kinase/MAP kinase activation (44). We therefore postulate that the rapid stimulation of eNOS by $\mathrm{E}_{2}$ is due to an increase in intracellular calcium that is mediated by tyrosine kinase/MAP kinase activation.

There is strong evidence from both human and animal studies that estrogen is protective against vascular injury and atherosclerosis. This occurs both indirectly by an effect on lipoprotein metabolism and directly through effects on the vessel wall, including alterations in vascular cell gene expression, mediated at least in part by ER $\alpha$ acting as a ligand-activated transcription factor. However, the beneficial effects of estrogen also have an important rapid component in the vasculature, which includes the acute activation of endothelial NO production (10,11,16-19). The present observations indicate that ER $\alpha$ may mediate the latter 
process, revealing for the first time that this protein regulates physiologic responses in a nongenomic fashion independent of its known ability to control transcription. As such, our current conceptualization of steroid hormone receptor function may be too narrow.

Along with the implications regarding estrogen and vascular endothelial function, the present findings are important to the mechanisms underlying the rapid effects of estrogen in a variety of other cell types. For example, the effects of opioids on hypothalamic neurons are acutely blunted by $\mathrm{E}_{2}$, and this response is attenuated by ER antagonism (5). In addition, $\mathrm{E}_{2}$ rapidly inhibits acid production and alters cell shape in osteoclasts in a receptor-dependent manner (45). Similarly, there are rapid, nongenomic, receptor-mediated effects of the hormone that ultimately regulate the growth of oncogenic cells $(7,8)$. Thus, the acute activation of ER $\alpha$ is likely to be important in a myriad of cellular responses to estrogen. Further studies of the rapid activation of ER $\alpha$ in endothelium, using models such as the ER $\alpha$ knockout mouse, will enhance both our specific knowledge of the role of estrogen in the vasculature and in other tissues and our general understanding of the nongenomic functions of steroid hormone receptors.

\section{Acknowledgments}

We are indebted to Marilyn Dixon for preparing this manuscript. This work was supported by National Institutes of Health grants HL58888, HL53546, and HD30276 (to P.W. Shaul), HL30386 (to R.H. Karas), and HL56069 and HL59953 (to M.E. Mendelsohn). The project was supported, in part, by the Lowe Foundation and was done during the tenure of Established Investigatorships of the American Heart Association (P.W. Shaul and M.E. Mendelsohn).

1. Kumar, V., et al. 1987. Functional domains of the human estrogen receptor. Cell. 51:941-951.

2. Evans, R.M. 1988. The steroid and thyroid hormone receptor superfamily. Science. 240:889-895.

3. Carson-Jurica, M.A., Shrader, W.T., and O’Malley, B.W. 1990. Steroid receptor family: structure and functions. Endocr. Rev. 11:201-220.

4. Wehling, M. 1997. Specific nongenomic actions of steroid hormones. Annu. Rev. Physiol. 59:365-393.

5. Lagrange, A.H., Ronnekleiv, O.K., and Kelly, M.J. 1997. Modulation of G protein coupled receptors by an estrogen receptor that activates protein kinase A. Mol. Pharmacol. 51:605-612.

6. Endoh, H., et al. 1997. Rapid activation of MAP kinase by estrogen in the bone cell line. Biochem. Biophys. Res. Commun. 235:99-102.

7. Migliaccio, A., et al. 1996. Tyrosine kinase/p21 $1^{\text {ras }} / \mathrm{MAP}-k i n a s e$ pathway activation by estradiol-receptor complex in MCF-7 cells. EMBOJ. 15:1292-1300.

8. Di Domenico, M., Castoria, G., Bilancio, A., Migliacio, A., and Auricchio, F. 1996. Estradiol activation of human colon carcinoma-derived Caco-2 cell growth. Cancer Res. 56:4516-4521.

9. Meizel, S., and Turner, K.O. 1991. Progesterone acts at the plasma membrane of human sperm. Mol. Cell. Endocrinol. 77:R1-R5

10. Mendelsohn, M.E., and Karas, R.H. 1994. Estrogen and the blood vessel wall. Curr. Opinion Cardiol. 9:619-626.

11. Farhat, M.Y., Lavigne, M.C., and Ramwell, P.W. 1996. The vascular protective effects of estrogen. FASEB J. 10:615-624.

12. Barrett-Connor, E., and Bush, T.L. 1991. Estrogen and coronary heart disease in women. JAMA. 265:1861-1867.

13. Grady, D., et al. 1992. Hormone therapy to prevent disease and prolong life in postmenopausal women. Ann. Intern. Med. 117:1016-1037.

14. Stevenson, J.C., Crook, D., Godsland, I.F., Collins, P., and Whitehead, M.I. 1994. Hormone replacement therapy and the cardiovascular system. Nonlipid effects. Drugs. 47:35-41.

15. Guetta, V., and Cannon, R.O., III. 1996. Cardiovascular effects of estrogen and lipid-lowering therapies in postmenopausal women. Circulation. 93:1928-1937.

16. Williams, J.K., Adams, M.R., Herrington, D.M., and Clarkson, T.B. 1992 Short-term administration of estrogen and vascular responses of atherosclerotic coronary arteries. J. Am. Coll. Cardiol. 20:452-457.

17. Reis, S.E., et al. 1994. Ethinyl estradiol acutely attenuates abnormal coronary vasomotor responses to acetylcholine in postmenopausal women.
Circulation 89.52-60.

18. Gilligan, D.M., Badar, D.M., Panza, J.A., Quyyumi, A.A., and Cannon, R.O. 1994. Acute vascular effects of estrogen in postmenopausal women. Circulation. 90:786-791.

19. Guetta, V., et al. 1997. The role of nitric oxide in coronary vascular effects of estrogen in postmenopausal women. Circulation 96:2795-2801.

20. Moncada, S., and Higgs, A. The L-arginine-nitric oxide pathway. 1993. N. Engl. J. Med. 329:2002-2012

21. Lantin-Hermoso, R.L., et al. 1997. Estrogen acutely stimulates nitric oxide synthase activity in fetal pulmonary artery endothelium. Am. J. Physiol. 273:L119-L126

22. Caulin-Glaser, T., Watson, C.A., and Bender, J.R. 1997. 17 $\alpha$-estradiol regulation of human endothelial cell basal nitric oxide release, independent of cytosolic $\mathrm{Ca}^{2+}$ mobilization. Circ. Res. 81:885-892.

23. Venkov, C.D., Rankin, A.B., and Vaughn, D.E. 1996. Identification of authentic estrogen receptors in cultured endothelial cells. A potential mechanism for steroid hormone regulation of endothelial function. Circulation. 94:727-733.

24. Kim-Schulze, S., et al. 1996. Expression of an estrogen receptor by human coronary artery and umbilical vein endothelial cells. Circulation. 94:1402-1407.

25. Kuiper, G.G.J.M., and Gustafsson, J.-A. 1997. The novel estrogen receptor- $\beta$ subtype: potential role in the cell- and promoter-specific actions of estrogens and anti-estrogens. FEBS Lett. 410:87-90.

26. Shaul, P.W., and Wells, L.B. 1994. Oxygen modulates nitric oxide production selectively in fetal pulmonary endothelial cells. Am. J. Respir. Cell Mol. Biol. 11:432-438.

27. Davda, R.K., Chandler, L.J., Crews, F.T., and Guzman, N.J. 1993. Ethanol enhances the endothelial nitric oxide synthase response to agonists. Hypertension. 21:939-943.

28. Shaul, P.W., Farrar, M.A., and Zellers, T.M. 1992. Oxygen modulates endothelium-derived relaxing factor production in fetal pulmonary arteries. Am. J. Physiol. 262:H355-H364.

29. Guo, J.P., Murohara, T., Buerke, M., Scalia, R., and Lefer, A.M. 1996. Direct measurement of nitric oxide release from vascular endothelial cells. $J$. Appl. Physiol. 81:774-779.

30. Liu, L.H., et al. 1997. Defective endothelium-dependent relaxation of vascular smooth muscle and endothelial cell $\mathrm{Ca}^{2+}$ signaling in mice lacking sarco(endo)plasmic reticulum $\mathrm{Ca}^{2+}$-ATPase isoform 3. J. Biol. Chem. 272:30538-30545.

31. Weih, M.K., Weikert, S., Freyer, D., and Dirnagl, U. 1998. Chemiluminescence detection of nitric oxide production from rat cerebral cortical endothelial cells in culture. Brain Res. Brain Res. Protoc. 2:175-182.

32. Jun, S.S., Chen, Z., Pace, M.C., and Shaul, P.W. Glucocorticoids downregulate cyclooxygenase-1 gene expression and prostacyclin synthesis in fetal pulmonary artery endothelium. Circ. Res. In press.

33. Wakeling, A.E., Dukes, M., and Bowler, J. 1991. A potent specific pure antiestrogen with clinical potential. Cancer Res. 51:3867-3873.

34. MacRitchie, A.N., et al. 1997. Estrogen upregulates endothelial nitric oxide synthase gene expression in fetal pulmonary artery endothelium. Circ. Res. 81:355-362.

35. Ponglikitmongkol, M., Green, S., and Chambon, P. 1988. Genomic organization of the human estrogen receptor gene. EMBO J. 7:3385-3388.

36. Shaul, P.W., et al. 1996. Acylation targets endothelial nitric oxide synthase to plasmalemmal caveolae. J. Biol. Chem. 271:6518-6522.

37. Marsen, T.A., Simonson, M.S., and Dunn, M.J. 1995. Thrombin induces the preproendothelin-1 gene in endothelial cells by a protein tyrosine kinase-linked mechanism. Circ. Res. 76:987-995.

38. Alessi, D.R., Cuenda, A., Cohen, P., Dudley, D.T., and Saltiel, A.R. 1995. PD 098059 is a specific inhibitor of the activation of mitogen-activated protein kinase kinase in vitro and in vivo. J. Biol. Chem. 270:27489-27494.

39. Turnbull, A.C., et al. 1974. Significant fall in progesterone and rise in oestradiol levels in human peripheral plasma before onset of labour. Lancet. 1:101-103.

40. Cousins, L.M., Hobel, C.J., Chang, R.J., Okada, D.M., and Marshall, J.R. 1977. Serum progesterone and estradiol-17beta levels in premature and term labor. Am. J. Obstet. Gynecol. 127:612-615.

41. Rosselli, M., Imthurn, B., Macas, E., Keller, P.J., and Dubuy, R.K. 1994. Circulating nitrite/nitrate levels increase with follicular development: indirect evidence for estradiol mediated NO release. Biochem. Biophys. Res. Commun. 202:1543-1552.

42. Hashimoto, M., et al. 1995. Modulation of endothelium-dependent flowmediated dilatation of the brachial artery by sex and menstrual cycle. Circulation. 92:3431-3435.

43. Wyckoff, M.H., Yuhanna, I.S., Pace, M.C., Mendelsohn, M.E., and Shaul, P.W. 1998. Plasma membrane-associated estrogen receptors mediate the acute activation of eNOS by estrogen. Circulation. 98:I312. (Abstr.)

44. Fleming, I., Fisslthaler, B., and Busse, R. 1995. Calcium signaling in endothelial cells involves activation of tyrosine kinases and leads to activation of mitogen-activated protein kinases. Circ. Res. 76:522-529.

45. Brubaker, K., and Gay, C.V. 1994. Specific binding of estrogen to osteoclast surface. Biochem. Biophys. Res. Commun. 200:899-907. 